Anetta Cubała ${ }^{1}$, Jarosław Hoffman ${ }^{2,3}$, Wojciech Hagner ${ }^{3}$, Tomasz Jurkiewicz, Paweł Molski ${ }^{5}$, Dorota Ratuszek ${ }^{3}$, Maciej Śniegocki ${ }^{4}$, Agnieszka Nowacka ${ }^{1}$

\title{
EFFECT OF MCKENZIE METHOD ON THE SEVERITY AND LOCATION OF PAIN IN PATIENTS WITH LUMBO-SACRAL DISCOPATHY
}

\author{
WPŁYW METODY MCKENZIEGO NA NASILENIE I LOKALIZACJĘ BÓLU \\ U PACJENTÓW Z DYSKOPATIĄ ODCINKA LĘDŹWIOWO-KRZYŻOWEGO
}

\section{Chair and Clinic of Rehabilitation, Nicolaus Copernicus University in Toruń, Collegium Medicum in Bydgoszcz Head: dr hab. n. med. Wojciech Hagner, prof. UMK \\ 1. Department of Neurosurgery and Neurotraumatology, Nicolaus Copernicus University, Collegium \\ Medicum in Bydgoszcz \\ 2. Gdansk Management College \\ 3. Department of Rehabilitation, Nicolaus Copernicus University, Collegium Medicum in Bydgoszcz} 4. Department of Neurotraumatology, Nicolaus Copernicus University, Collegium Medicum in Bydgoszcz 5. Department of Physiotherapy, Eskulap Health Centre in Bydgoszcz

\section{Sum mary}

Lumbar spine discopathy is a serious social and economical problem in both our country and around the world. The severity of pain significantly impairs the performance of basic activities such as: dressing, walking, sitting, sleeping, traveling, social and sexual life that make up the quality of life.

The aim of the study is to investigate the effect of rehabilitation conducted by McKenzie method on the value and localization of pain ailments.

The study included 45 patients treated for pain ailments accompanying lumbar discopathy, in whom the analogue VAS scale was used to assess pain.

There was no effect of gender, age and number of episodes of pain on the location of the pain. Pain ailments increased during bending $(95.6 \%, \mathrm{~N}=43)$, standing up $(88.9 \%, \mathrm{~N}=40)$ and standing $(48.9 \%, \mathrm{~N}=22)$, and decreased during lying down $(77.8 \%, \mathrm{~N}=35)$ and walking $(73.3 \%, \mathrm{~N}=33)$. McKenzie method treatment significantly influenced the location of the pain, because prior to treatment, patients experienced pain: within the leg and foot $(40 \%, \mathrm{~N}=18)$, thighs $(36 \%, \mathrm{~N}=16)$ and sacrum $(24 \%, \mathrm{~N}=$ 11 ) and after therapy, these proportions were : $0 \%: 4 \%: 29 \%$ and $67 \%$, respectively experienced no pain. Pain rated on a VAS scale decreased significantly from $6.58 \pm 1.6$ to $0.76 \pm$ 0.86 . Number of patients taking painkillers directly $(66.7 \%$, $\mathrm{N}=30)$ and consistently $(22.2 \%, \mathrm{~N}=10)$ after the treatment was limited to only 1 patient receiving medications directly $(2.22 \%, \mathrm{~N}=1)$.

McKenzie therapy significantly reduces the severity of pain ailments associated with lumbar discopathy, and also limits their range.

\section{Streszczenie}

Dyskopatia odcinka lędźwiowo-krzyżowego kręgosłupa stanowi poważny problem społeczny i ekonomiczny zarówno w naszym kraju jak i na świecie. Nasilenie dolegliwości bólowych w znaczny sposób upośledzają wykonywanie podstawowych czynności składających się, na jakość życia, takich jak: ubieranie, chodzenie, siedzenie, spanie, podróżowanie, życie seksualne i socjalne.

Celem pracy jest zbadanie wpływu rehabilitacji prowadzonej metodą McKenziego na wielkość i lokalizację dolegliwości bólowych. 
Badaniem objęto 45 pacjentów leczonych $\mathrm{z}$ powodu dolegliwości bólowych towarzyszących dyskopatii odcinka lędźwiowo-krzyżowego, u których do oceny bólu zastosowano analogową skalę VAS.

Nie stwierdzono wpływu płci, wieku i liczby epizodów bólowych na lokalizację bólu. Dolegliwości bólowe narastały przy zginaniu $(95,6 \% ; \mathrm{N}=43)$, wstawaniu $(88,9 \% ; \mathrm{N}=40)$ i staniu $(48,9 \% ; \mathrm{N}=22)$, a zmniejszały w trakcie leżenia $(77$, $8 \% ; \mathrm{N}=35)$ i chodzenia $(73,3 \% ; \mathrm{N}=33)$. Leczenie metodą McKenziego wpłynęło istotnie statystycznie na lokalizację bólu, gdyż przed terapią pacjenci odczuwali ból: w obrębie goleni i stopy $(40 \% ; \mathrm{N}=18)$, uda $(36 \% ; \mathrm{N}=16)$ i krzyża $(24 \%$; $\mathrm{N}=11)$, a po terapii proporcje te kształtowały się

Key words: Mckenzie method, discopathy, pain

Stowa kluczowe: metoda Mckenziego, dyskopatia, dolegliwości bólowe

\section{INTRODUCTION}

Low back pain syndrome is a problem in highly developed countries. However, the current level of knowledge about lumbar pain is relatively small. In 1934, Mixter and Barr published an article about the consequences of neurological damage to the intervertebral disc in the New England Journal of Medicine. Finding effective treatments seems to be one of the most important directions of research in recent years, granted in the past period, bone and joint decade 2000-2010 [1].

Illnesses and injuries epidemiological data, from which it follows that back pain are the cause of staying in bed for 93.4 million days per year and 240 million days of work incapacity, testify about the scale of the problem. Both numbers represent almost half of value that is applied to all other musculoskeletal system diseases. It is estimated that $80 \%$ of adults older than 30 years will experience different severity pain ailments around the back at least once [2-4].

McKenzie method offers a different way of back pain treatment. With this method examination, treatment and prevention overlap throughout treatment. Since first days of therapy the patient is taught how to perform activities of daily living in an ergonomic way. Characteristic for this method is an effective treatment for current episode of illness and prevention of relapses. McKenzie method is not very common and is not a method of choice for treatment of lumbar spine pain syndromes.

Studies of the impact of McKenzie method on the severity and location of pain in patients with lumbar discopathy seem to be the most appropriate and justified. odpowiednio: $0 \%$ : 4\% : 29\%, a u $67 \%$ nie występowały dolegliwości bólowe. Dolegliwości bólowe oceniane w skali VAS zmniejszyły się istotnie z $6,58 \pm 1,6$ do $0,76 \pm 0,86$. Liczba pacjentów przyjmujących leki przeciwbólowe doraźnie $(66,7 \% ; \mathrm{N}=30)$ i stale $(22,2 \% ; \mathrm{N}=10)$ po terapii ograniczyła się tylko do 1 pacjenta przyjmującego leki doraźnie $(2,22 \% ; \mathrm{N}=1)$.

Terapia McKenziego zmniejsza w stopniu istotnym nasilenie dolegliwości bólowych związanych z dyskopatią odcinka lędźwiowo-krzyżowego, a także ogranicza ich zasięg.
The study included a group of 45 patients treated for pain ailments associated with lumbar spine discopathy who gave written consent to participate in the study (KB /276/260). The research was conducted in 2007-2008 of the Anthony Jurasz University Hospital Rehabilitation Clinic in Bydgoszcz. In the study group there were 17 women and 28 men, aged from 18 to 74 years. The mean age of patients was 41.3 \pm 12.8 years. The mean age of men and women did not differ statistically (42.5 years for women and 40.5 years for men, $\mathrm{p}=0.619$ ).

The following patients were qualified to the study: professionally active and retired, with the first incident lasting more than a month, with recurrence of discopathy symptoms in history, without improvement after other treatment methods.

During the study patients did not use other treatment methods. Therapy was conducted by a certified McKenzie method therapist.

The diagnosis of disk etiology was erected based on the results of subjective and objective patient examination according to the McKenzie method. According to the McKenzie method, slipped disc symptoms are: back pain, radicular pain, muscle weakness and paresthesia within the spinal nerve, as well as positive distraction tests results.

\section{RESULTS}

Patients were rehabilitated from 7 up to 90 days, median rehabilitation time was 28 days. The largest number of patients felt increscent of pain ailments severity during bending $(95.6 \%, \mathrm{~N}=43)$ and standing up $(88.9 \%, \mathrm{~N}=40)$. Totally, 39 people $(86.7 \%)$ have 
felt pain during these two activities. 35 (77.8\%) patients felt reduction of pain while lying down, and 33 (73.3\%) during walking. There were no gender differences in the perception of pain associated with analyzed activities ( $\mathrm{p}>0.05)$.

The pain value, evaluated by VAS scale, prior to therapy ranged from 3 to 10 points, $6.58 \pm 1.6$ points mean. After the therapy the value of pain ailments decreased significantly highly and ranged from 0 to 4 points, an average of $0.76 \pm 0.86$ points $(p=0.00000)$. Distribution of the number of patients relative to the value of pain ailments evaluated by VAS scale at the beginning and end of active treatment are shown in Fig. 1.

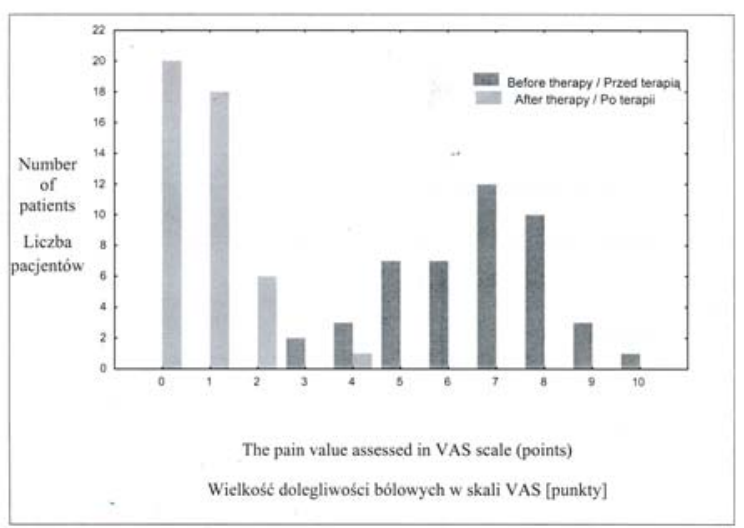

Fig. 1. Distribution of the number of patients relative to the value of pain ailments evaluated by VAS scale at the beginning and end of active treatment

Ryc. 1. Rozktad liczby pacjentów względem wielkości dolegliwości bólowych ocenianych w skali VAS na poczqtku i na końcu terapii

Under the influence of the applied therapy, the value change in pain ailments assessed by VAS scale was dependent on the value of the initial pain. The greater the feeling of pain was before treatment, the greater improvement was found after treatment, the correlation coefficient $r=-0.90(p<0.001)$.

A treatment by McKenzie method significantly influenced the location of pain $(p=0.00000)$ (Tab. I). Before McKenzie method treatment, in the studied group of patients, pain of a lower leg and foot (40\%; $\mathrm{N}=18$ ) usually occurred. After the therapy, pain disappeared in 30 patients $(66.7 \%)$, and none of the patients signaled nor leg neither foot pain. There was no influence of gender and age of patients on the location of pain $(p>0.05)$. Also, in patients in the study group, the time from the first episode and number of episodes of pain did not affect the location of the last episode pain $(\mathrm{p}>0.05)$.
Table I. Pain topography before and after McKenzie method therapy.

Tabela I. Topografia bólu przed $i$ po leczeniu metoda McKenziego

\begin{tabular}{|c|c|c|c|c|}
\hline & \multicolumn{3}{|c|}{ Before therapy Przed terapia } & \multicolumn{2}{|c|}{ After therapy Po terapii } \\
\cline { 2 - 5 } & $\mathrm{N}$ & $\%$ & $\mathrm{~N}$ & $\%$ \\
\hline $\begin{array}{c}\text { No pain } \\
\text { Brak bólu }\end{array}$ & 0 & 0,0 & 30 & 66,7 \\
\hline $\begin{array}{c}\text { Local pain } \\
\text { Ból miejscowy }\end{array}$ & 11 & 24,4 & 13 & 28,9 \\
\hline $\begin{array}{c}\text { Upper leg pain } \\
\text { Ból uda }\end{array}$ & 16 & 35,6 & 2 & 4,4 \\
\hline $\begin{array}{c}\text { Lower leg and foot pain } \\
\text { Ból goleni i stopy }\end{array}$ & 18 & 40,0 & 0 & 0,0 \\
\hline
\end{tabular}

Under the influence of therapy, pain disappeared in $90.9 \%$ of patients with local pain (in the lumbosacral area) prior to treatment, in $68.8 \%$ of patients with thigh pain before treatment and in $50.0 \%$ of patients with leg and foot pain prior to treatment.

Analgesics before the treatment were used by 40 people $(88.9 \%), 30$ people $(66.7 \%)$ ad hoc and 10 people $(22.2 \%)$ daily. After completion of rehabilitation under the supervision of a certified therapist one person reported the need for occasional pain medication.

\section{DISCUSSION}

Pain ailments in the lumbar-sacral spine influence the quality of patient's life. Quality of life is the patient's ability to perform the basic tasks necessary to function in society as dressing, sitting, sleeping, traveling, sexual and social aspects. The severity of pain significantly impairs the accomplishment of these activities, thus the quality of patients life is reduced [58]. In turn, the reduction of quality of patients' life implies important economic aspect of lumbosacral discopathy, which is the result of sickness absence and size of cash benefits, downloaded for permanent incapacity for work [2-4, 9-11].

Therefore, in this study a 10 - point VAS scale was used for pain assessment. Our study showed that before treatment, all patients had reported pain that affected leg and foot (40\%), thighs (36\%) and around the sacrum $(24 \%)$. It should be noted that the location of the pain did not affect either the patient's age, gender, or number of episodes of pain. Pain ailments underwent intensity during bending movements (95.6\%), and also while standing up (88.9\%) and standing (48.9\%), and significantly decreased while lying down $(77.8 \%)$ and walking $(73,3 \%)$. The observed factors exacerbating and alleviating pain ailments are confirmed in the professional literature. 
Dursten et al. surveyed 100 patients by asking them a question about the pain felt during the various activities of daily living. Activities exacerbating symptoms the most were as follows: sitting (85\%), bending (78\%), state (73\%) and standing up (70\%) [12].

Also Boissonnault et al. surveyed 98 patients with low back pain, asking for factors exacerbating and alleviating symptoms. Factors aggravating symptoms were: sitting, driving, bending and lifting. The most common exacerbating factors were lying, frequent changes of position and walking [13].

After applying McKenzie method treatment, in 2/3 of patient's pain disappeared completely, and none of them complained of leg and feet pain. These data permit the conclusion that the therapy reduces the scope of pain, by removing leg and foot pain. As a result of carried out rehabilitation, centralization of pain was observed, which is crucial for the McKenzie method.

Little-known clinical phenomenon of centralization has been observed by Robin McKenzie in 1956. He noticed that this phenomenon can be very useful in evaluating and treating patients with lumbar discopathy. Recovery is based on regression of the problems towards the back. The idea of this method is to seek such a movement or positions that will move the pain from distal to proximal parts. In case of back pain only, a phenomenon of centralization is to reduce the area covered by the pain to a more central location, and then eliminate the pain. During centralization, the fact that back pain may even temporarily increase in intensity, while resolution of symptoms in the distal part, is interesting $[14,15]$.

Like McKenzie, many researchers found centralization phenomenon to be the most useful in the diagnosis and treatment of patients with lumbar spine pain. Many authors such as: Long, Sufka et al., Donelson et al., Werneke et al. suggest that patients with centralization achieve significantly better outcomes than patients without symptoms of centralization [16-19].

Long in the study on 223 patients received the effect of centralization in $47 \%$ of the study group. Comparing patients with and patients without centralization, he highlighted a significant difference in reducing the maximum rate of improvement between the two groups: $16 \%$ and $6 \%$, respectively. Long also studied the impact of centralization on the return to work. Results showed that patients who had experienced centralization of symptoms reported higher rates of return to work (68\%) than patients who had had no centralization of symptoms (52\%) [13].

When studying a group of 87 patients Donelson et al. found that rapid centralization occurred in 76 patients $(89 \%)$, and each patient was followed with the centralization of the limited ranges of motion improved. In most cases the improvement occurred during the first visit, and in rest of the group within two days. The final outcome was excellent in $83 \%$ of patients in whom there had been centralization. The same results in the group without centralization were showed in only $17 \%$ of patients. Statistical analysis of results showed a highly significant correlation between the prevalence of centralization and good or very good results, as well as between the lack of centralization and unsatisfactory outcomes. Donelson concludes that the inability to obtain centralization indicates the unfavorable prognosis of treatment. He believes the phenomenon of centralization as very useful, because by observing the location of pain patients may use exercises centralizing symptoms and avoid movements and position of the spine in the opposite direction. It protects them from peripheral back pain. Therefore, the patient also takes responsibility for minimizing and stabilizing pain [5].

Comparing the number of patients who have experienced the phenomenon of centralization in the present study with studies of other authors, a large discrepancy of results was found. In our study, the centralization of symptoms occurred in more than $97 \%$ of the study group, which corresponds more with the data by Donelson (87\%) than by Longa (47\%). It should be emphasized that all three study groups were similar in terms of age and gender. The average age in our study was 41 years (62\% men and 38\% women), Donelson's study - 37 years (43\% men and $57 \%$ of women), and in Longa's material - 39 years (70\% men and $30 \%$ women). Differences in numbers of patients with symptoms of centralization between the different studies may be due to patient selection criteria for participation in the study. In our study, patients applying for or benefiting from fixed cash benefits for permanent or temporary incapacity to work due to spinal complaints, were excluded. In addition, all patients were professionally active, or benefited from retirement benefits. In the study of Donelson $42 \%$ of patients remained in the interim release due to discopathy, while in Long's study sick leave applied to all patients. Another reason for this significant 
difference may be that we excluded patients with a first incident within less than one month. Probably, patients with a first attack of low back pain early in the disease do not know about the possibility of future attacks. The experience of the therapist also influences the outcome of the therapy. Donelson indicates a common mistake with inexperienced therapists, which is inaccurate observation of symptoms of reaction to mechanical stress and suppress the progression of force rules. These errors prevent the occurrence of centralization of symptoms and difficult accuracy of the assessment and degrade the outcomes. The method promoted in this work is safe and very effective, provided that it is run by well-trained therapist in the McKenzie method.

Basing on the concept of McKenzie, it can be concluded that patients in whom there was no centralization of symptoms are characterized by intact hydrostatic mechanism of intervertebral discs. In this case the fibrous ring does not affect the position of the nucleus pulpous. The concept of McKenzie is addressed to patients with protrusion of intervertebral discs. In patients with disc extrusion and sequestration, where the hydrostatic mechanism is compromised, the concept of McKenzie cannot influence the position of the nucleus pulpous $[5,16,20]$.

Machado et al. performed a multi-centre randomized controlled trial with a 3-month follow-up in 148 people with acute non-specific low back pain. Eligible participants were assigned to receive a treatment program based on the McKenzie method and first-line care (advice, reassurance and time-contingent acetaminophen) or first-line care alone, for 3 weeks. Primary outcome measures included pain (0-10 Numeric Rating Scale) over the first seven days, pain at 1 week, pain at 3 weeks and global perceived effect ( -5 to 5 scale) at 3 weeks. Treatment effects were estimated using linear mixed models. The addition of the McKenzie method to first-line care produced statistically significant but small reductions in pain when compared to first-line care alone: mean of -0.4 points $(95 \%$ confidence interval, -0.8 to -0.1$)$ at 1 week, -0.7 points ( $95 \%$ confidence interval, -1.2 to $0.1)$ at 3 weeks, and -0.3 points $(95 \%$ confidence interval, -0.5 to -0.0 ) over the first 7 days. Patients receiving the McKenzie method did not show additional effects on global perceived effect, disability, function or on the risk of persistent symptoms. These patients sought less additional health care than those receiving only first-line care $(\mathrm{P}=0.002)$. When added to the currently recommended first-line care of acute low back pain, a treatment program based on the McKenzie method does not produce appreciable additional short-term improvements in pain, disability, function or global perceived effect. However, the McKenzie method seems to reduce health utilization although it does not reduce patient's risk of developing persistent symptoms. ${ }^{22}$

An ability to identify groups of patients who have failed to centralization of symptoms is important, because they can save time and money spent on ineffective conservative treatment and possible further diagnosis and surgery [21].

Al-Obaidi et al. performed a prospective cohort study with a follow-up in 62 volunteers with chronic low back pain (28 men, 34 women; average age 41.9 and 37.1 years, respectively) qualified for McKenzie intervention. Significant improvements peaked at the end of the 5th week for all outcome measures $(\mathrm{P}<$ .001 ), with slight increase in bio-behavioral variables at the end of the 10th week. McKenzie intervention reduced pain and related fear and disability beliefs, and improved physical performances in individuals with chronic low back pain. Improvements in physical performances remained stable 10 weeks after treatment, regardless of the elevation in bio-behavioral factors [23].

Werneke believes that if the dynamic assessment of changes in response to therapeutic interventions will not reveal the phenomenon of centralization within 7 visits, patient prognosis is poor, compared with patients with centralization. Patients classified as noncentralization should be monitored and require further investigation [19].

Our study showed that the McKenzie method significantly reduced pain intensity measured by the VAS scale. Before therapy started, the mean value of pain was 6 , and post-treatment values decreased to 0.8 . This was also reflected in the discontinuation of analgesics. At the beginning of the therapy in the study group $88.9 \%$ were taking analgesics daily or occasionally. Our study also showed that greater improvements were achieved in these patients in whom the pain before treatment had been stronger. These data suggest that McKenzie therapy significantly reduces the severity of pain ailments. After the completion of therapy, only one patient reported the need of use of these medicines. Also studies of other authors confirm the effectiveness of the presented method. Fowler, Grant and Goldby emphasize the significant benefits of McKenzie method for patients with spinal pain [2426]. 


\section{CONCLUSIONS}

The McKenzie therapy significantly reduces the severity of pain associated with lumbar discopathy, and also limits their range.

\section{REFERENCES}

1. Dziak A. Bolesny krzyż. . Kraków: Medicina Sportiva; 2003.

2. Analysis of measures of musculoskeletat diseases and injuries. Amer Acad of Ortop Surg. 1998.

3. Frymoyer JW. The Adult Spine: Principles and Practice. Philadelphia: Lippincott-Raven; 1997.

4. Parker H, Wood PL, Main CJ. The use of the pain drawing as a screening measure to predict psychological distress in chronic low back pain. Spine. Jan 15 1995;20(2):236-243.

5. Bulpitt CJ. Quality of life as an outcome measure. Postgraduate medical journal. Oct 1997;73(864):613616.

6. Glinkowski W, Ciszek, B. Wybrane zagadnienia morfologii i właściwości krążków międzykręgowych. Ortopedia Traumatologia Rehabilitacja. 2004;6:141-148.

7. Muncey H, Giles, F., Harper, B. Standards for physiotherapists working in pain management programmes. The Chartered Society of Physiotherapy. London1998.

8. Triano JJ, McGregor M, Skogsbergh DR. Use of chiropractic manipulation in lumbar rehabilitation. Journal of rehabilitation research and development. Oct 1997;34(4):394-404.

9. Cypress BK. Characteristics of physician visits for back symptoms: a national perspective. American journal of public health. Apr 1983;73(4):389-395.

10. Dziak A. Bóle krzyża. Warszawa: PZWL; 1997.

11. Frymoyer JW. Back pain and sciatica. The New England journal of medicine. Feb 4 1988;318(5):291-300.

12. Deursen L, Snijders, C., Patijn, J. Influence of daily life activities on pain in patients with low back pain. $J$. Ortopedic. Med. 2002;24:74- 76.

13. Boissonnault W, Fabio RP. Pain profile of patients with low back pain referred to physical therapy. The Journal of orthopaedic and sports physical therapy. Oct 1996;24(4):180-191.

14. Donelson R, Silva G, Murphy K. Centralization phenomenon. Its usefulness in evaluating and treating referred pain. Spine. Mar 1990;15(3):211-213.

15. Polska IM. Kręgosłup lędźwiowy, Poznań.

16. Karas R, McIntosh G, Hall H, Wilson L, Melles T. The relationship between nonorganic signs and centralization of symptoms in the prediction of return to work for patients with low back pain. Physical therapy. Apr 1997;77(4):354-360; discussion 361-359.
17. Long AL. The centralization phenomenon. Its usefulness as a predictor or outcome in conservative treatment of chronic law back pain (a pilot study). Spine. Dec 1 1995;20(23):2513-2520; discussion 2521.

18. Sufka A, Hauger B, Trenary M, et al. Centralization of low back pain and perceived functional outcome. The Journal of orthopaedic and sports physical therapy. Mar 1998;27(3):205-212.

19. Werneke M, Hart DL. Centralization phenomenon as a prognostic factor for chronic low back pain and disability. Spine. Apr 1 2001;26(7):758-764; discussion 765.

20. McKenzie R. The lumbar spine: mechanical diagnosis and therapy. Wellington: Spinal Publications; 1981.

21. Marcinek W, Szulc, A. Wiktora Degi Ortopedia $i$ Rehabilitacja. . Warszawa: PZWL; 2004.

22. Machado LA, Maher CG, Herbert RD, Clare H, McAuley JH. The effectiveness of the McKenzie method in addition to first-line care for acute low back pain: a randomized controlled trial. BMC medicine. 2010;8:10.

23. Al-Obaidi SM, Al-Sayegh NA, Ben Nakhi H, AlMandeel M. Evaluation of the McKenzie intervention for chronic low back pain by using selected physical and biobehavioral outcome measures. $P M \& R$ : the journal of injury, function, and rehabilitation. Jul 2011;3(7):637646; quiz 646.

24. Fowler B, Oyekoya, O. The therapeutic efficacy of McKenzie Concept in the management of low back pain. Proceedings 12 International Congress World Confederation Physical Therapists. Washington, USA1995.

25. Goldby L. A randomized controlled trial comparing the McKenzie method of mechanical diagnosis and therapy with a non-prescriptive exercise regime in the conservative treatment of chronic low back pain. Proceedings 4 McKenzie Institute International Conference. Cambridge, England1995.

26. Grand G, Gille, K., Degerfeldt, L. McKenzie method and functional training in back pain rehabilitation. A brief review including results from a four-week rehabilitation programme. Physical Therapy Reviews. 2000;5:107-115.

\section{Address for correspondence:}

\section{mgr Anetta Cubała}

Departament of Neurosurgery and Neurotraumatology, Nicolaus Copernicus University, Collegium Medicum in Bydgoszcz e-mail: anettacubala@gmail.com

Received: 10.01 .2012

Accepted for publication: 6.03.2012 